\title{
The Rapid Pyrolytic Characterization of Tobacco Leaf Carbohydrate Material *
}

\author{
by W. S. Schlotzhauer, R. F. Arrendale and O. T. Chortyk \\ Tobacco Safety Research Unit, Agricultural Research Service, \\ United States Department of Agriculture, Athens, Georgia, U.S.A.
}

\section{SUMMARY}

A rapid, semi-micropyrolysis technique was developed and applied to materials representative of tobacco cellwall constituents and sucrose. Glass capillary gas chromatography - mass spectrometry was used to separate and identify the major semi-volatile pyrolyzate components. Cellulose and dextrin produced a pattern of furan and cyclic ketones of potential importance to flavor and aroma of tobacco smoke. Sucrose pyrolysis resulted in the formation of substantial amounts of 2-furaldehyde and lesser quantities of substituted furans. The cell-wall biopolymer lignin was a source of phenols, but contributed little to the compounds produced in the thermal breakdown of carbohydrates.

\section{ZUSAMMENFASSUNG}

Mit einem von den Autoren entwickelten, schnellen Halbmikropyrolyseverfahren wurden Tabakzellwandbestandteile und Saccharose untersucht. Auftrennung und Identifizierung der wichtigsten halbflüchtigen Pyrolyseprodukte erfolgten mittels Kapillar-Gaschromatographie in Verbindung mit Massenspektrometrie. Aus Cellulose und Dextrin bildeten sich Furan und cyclische Ketone, die für den Geschmack und das Aroma von Tabakrauch von Bedeutung sein könnten. Durch die Pyrolyse der Saccharose entstanden erhebliche Mengen 2-Furfural und geringere Mengen substituierter Furane. Das Zellwand-Biopolymer Lignin war Ausgangsstoff für die Bildung von Phenolen, trug aber wenig Verbindungen bei, die während der thermischen Zersetzung von Kohlenhydraten entstehen.

\section{RESUME}

Le saccharose et certains éléments constitutifs de la paroi cellulaire du tabac ont été étudiés au moyen d'un procédé rapide de semi-micropyrolyse mis au point par les auteurs. $\mathrm{La}$ séparation et l'identification des plus importants des produits semi-volatils ainsi obtenus ont été effectuées par chromatographie capillaire en phase gazeuse associée à la spectrographie de masse. Du furane et des cétones cycliques qui pourraient être importants pour le goût et l'arôme de la fumée de tabac se sont formés à partir de la cellulose et de la dextrine. La pyrolyse du saccharose a conduit à la formation de quantités considérables de furfural-2 et à de faibles quantités de furanes substitués. La lignine, biopolymère du tissu cellulaire, a été un précurseur de phênols mais seulement dans une faible mesure de composés produits par la dégradation thermique des hydrates de carbone.

\section{INTRODUCTION}

Our need to pyrolytically evaluate a large number of tobacco samples has led to the presently reported improvement of our standard pyrolysis technique. As currently we employ mostly glass capillary gas chromatography (GC-2), which allows improved resolution of pyrolyzate components and lower sample concentrations, in our analyses, it is necessary to utilize a semi-micropyrolysis procedure that yields just sufficient material for GC-2 and is more rapid than our previous larger-scale tube pyrolysis method (1). The utility and validity of this semi-micropyrolysis/GC-2 method have been proven and are described here for tobacco leaf carbohydrates.

The distinctive aroma, flavor and biological properties

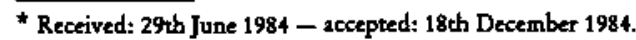


of tobacco smoke are attributable to the interactions of thousands of individual chemical components, the majority of which arise through pyrolytic reactions $(2,3)$. Tobacco leaf carbohydrates, comprising cell-wall biopolymers and reducing sugars, are of particular interest. Due to their refatively high concentration in the average cigarette tobacco blend and their low volatility, they should contribute significantly to pyrosynthesized smoke components. Several studies $(4,5,6)$ have shown carbohydrates to be major pyrosynthetic sources of furans, carbonyls and other flavor related smoke compounds. In addition, it has been suggested that the biological activity of cigarette smoke is directly affected by the sugar content of leaf $(7,8)$.

One of our research objectives has been the development of methods to determine the contributions of major tobacco leaf constituents to the formation of smoke compounds affecting overall flavor, aroma and biological properties. Presently, we are reporting the utilization of the rapid, semi-micropyrolysis method in combination with GC-2 and mass spectrometry (MS) to identify semi-volatile compounds arising from the thermal degradation of sugar (sucrose) and polysaccharides (cellulose and dextrin). Lignin is included because of its proximate presence with cellulose in cell walls.

\section{EXPERIMENTAL *}

\section{Materials}

$\alpha$-Cellulose and dextrin were obtained from Sigma Chemical Corporation; sucrose was Baker chemical reagent grade; lignin was isolated from Bright tobacco stalk by the method of Pepper (9); methylene chloride was Mallinckrodt distilled-over-glass quality.

\section{Pyrolysis}

Pyrolyses were performed in a microunit similar to a reported method (10). Selection of pyrolysis conditions was based on comparisons of tobacco leaf pyrolysis products, formed under varying conditions of temperature and gaseous environment, with cigarette smoke profiles. Ground tobacco (NC 2326 flue-cured lamina) was variously pyrolyzed at temperatures from $300^{\circ} \mathrm{C}$ to $800^{\circ} \mathrm{C}$ under nitrogen and/or air. Pyrolyzates obtained at $700^{\circ} \mathrm{C}$, under nitrogen, were found to correlate most closely with component profiles obtained from total particulate matter of NC 2326 cigarettes. Samples (5 to $10 \mathrm{mg}$ ) were weighed in quartz tubes $(25 \mathrm{~mm} \times 2 \mathrm{~mm}$ inside diameter) which were then positioned in a platinum-heating coil pyroprobe (Chemical Data Systems, Inc.). The probe was inserted and locked into a pre-

\footnotetext{
* Reference to a company or product name does not imply endorsement or recommendation by the U.S.D.A.
}

heated $\left(200^{\circ} \mathrm{C}\right)$ oven assembly, then swept with a continuous flow of dry nitrogen $(15 \mathrm{ml} / \mathrm{min})$. The heater coil was elevated to $700^{\circ} \mathrm{C}(8 \mathrm{~ms})$ and held for $10 \mathrm{~s}$. Semi-volatile pyrolysis products were flushed from the oven assembly by the nitrogen carrier gas, and the semi-volatile pyrolyzate effluent was allowed to condense, at room temperature, in a Pyrex glass $(2 \mathrm{~mm}$ inside diameter) ${ }^{\circ} \mathrm{U}^{*}$ tube. Pyrolyzates were recovered by elution with $50 \mu$ l of methylene chloride.

\section{Glass Capillary Gas Chromatography/ Mass Spectrometry}

Aliquots of the methylene chloride soluble pyrolyzates were removed and characterized with a Hewlett-Packard gas chromatograph - mass spectrometer (HP 5985) system. Components were resolved on a $35 \mathrm{~m} \times 0.2 \mathrm{~mm}$ inside diameter capillary column coated with SP-1000 (11). The oven temperature was programmed from $50^{\circ} \mathrm{C}$ to $250^{\circ} \mathrm{C}$ at $4 \% \mathrm{~min}$. Helium flow of $30 \mathrm{~cm} / \mathrm{s}$, splitless injection mode, MS scan rate of $400 \mathrm{u} / \mathrm{s}$, ion source temperature of $200{ }^{\circ} \mathrm{C}$, ion source energy of $70 \mathrm{eV}$, and electron multiplier of $2000 \mathrm{~V}$ were utilized. Identification of components was based on computer matching with combined National Bureau of Standards, Environmental Protection Agency, and National Institutes of Health spectral libraries, and comparison with published spectra (12).

\section{RESULTS AND DISCUSSION}

GC-2 chromatograms of pyrolyzate semi-volatiles of cellulose, dextrin, sucrose and lignin are shown in Fig. 1 through Fig. 4, respectively. Compounds identified by mass spectrometry and labeled on the chromatograms are listed in Table 1. Previous identifications of leaf component pyrolysis products $(13,14)$ or of smoke components $(15,16)$ have relied on conversions to volatile silyl derivatives to facilitate gas chromatographic separations. However, the use of the SP-1000 GC liquid phase and appropriate chromatographic conditions permitted the separations, without derivatization, of the semi-volatile components which are of particular interest to smoke flavor and aroma studies.

The pyrolytic products of cellulose have been extensively studied. Gardiner (17) and Saint-Jalm (13) identified 1,6-anhydroglycopyranose (levoglucosan) as the major thermal decomposition product of cellulose, under varying conditions. This compound is believed to be intermediate in the formation of cellulose pyrolysis products. We have previously found levoglucosan to be a major pyrolysis product, but its GC elution from SP-1000 required its conversion to a trimethylsilyl derivative, and was, therefore, not determined under our analysis conditions. Since the present study is concerned with semi-volatile compounds which affect to- 
Table 1.

Identfiled pyrolyzate components.

\begin{tabular}{|c|c|c|c|c|c|c|c|}
\hline \multirow{2}{*}{$\begin{array}{l}\text { Peak } \\
\text { No. }\end{array}$} & \multirow[b]{2}{*}{ Compound } & \multirow{2}{*}{$\begin{array}{l}\text { Molecular } \\
\text { weight }\end{array}$} & \multirow[b]{2}{*}{ Formula } & \multicolumn{4}{|c|}{$\begin{array}{l}\text { Percentage of total volatiles from } \\
\text { chromatograms of pyrolyzates of }\end{array}$} \\
\hline & & & & cellulose & dextrin & sucrose & lignin \\
\hline 1 & 2-Methylfuran & 82 & $\mathrm{C}_{5} \mathrm{H}_{8} \mathrm{O}$ & 0.3 & & & \\
\hline 2 & 3-Methylfuran & 82 & $\mathrm{C}_{5} \mathrm{H}_{6} \mathrm{O}$ & 6.1 & 19.9 & 3.0 & \\
\hline 3 & 2-Methyl-2-cyclopenten-1-one & 96 & $\mathrm{C}_{6} \mathrm{H}_{8} \mathrm{O}$ & & 2.0 & 0.3 & \\
\hline 4 & Propionic acid methyl ester & 88 & $\mathrm{C}_{4} \mathrm{H}_{8} \mathrm{O}_{2}$ & 1.1 & 2.5 & 0.6 & \\
\hline 5 & 2,4-Pentanedione & 100 & $\mathrm{C}_{5} \mathrm{H}_{8} \mathrm{O}_{2}$ & & 1.8 & 0.4 & \\
\hline 6 & 2-Methyl-2-pentenal & 98 & $\mathrm{C}_{6} \mathrm{H}_{10} \mathrm{O}$ & & 1.1 & & 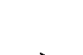 \\
\hline 7 & 5-Methyl-3-hydrofuran-2-one & 98 & $\mathrm{C}_{5} \mathrm{H}_{8} \mathrm{O}_{2}$ & & & 0.6 & \\
\hline 8 & 2-Furaldehyde & 96 & $\mathrm{C}_{5} \mathrm{H}_{4} \mathrm{O}_{2}$ & 20.7 & 16.7 & 67.1 & \\
\hline 9 & 2-Acetylfuran & 110 & $\mathrm{C}_{6} \mathrm{H}_{8} \mathrm{O}_{2}$ & 0.8 & & 0.7 & \\
\hline 10 & 5-Methyl-2-furaldehyde & 110 & $\mathrm{C}_{8} \mathrm{H}_{8} \mathrm{O}_{2}$ & 2.1 & 1.7 & 4.2 & \\
\hline 11 & 3,5,5-Trimethyl-2-cyclopenten-1-one & 124 & $\mathrm{C}_{8} \mathrm{H}_{12} \mathrm{O}$ & 0.7 & 0.6 & 0.5 & \\
\hline 12 & Dihydro-2(3/)-furanone & 86 & $\mathrm{C}_{4} \mathrm{H}_{0} \mathrm{O}_{2}$ & & & 0.7 & \\
\hline 13 & 2,3,4-Trimethyl-2-cyclopenten-1-one & 124 & $\mathrm{C}_{8} \mathrm{H}_{12} \mathrm{O}$ & & 1.1 & 0.9 & \\
\hline 14 & 2-Furanmethanol & 98 & $\mathrm{C}_{5} \mathrm{H}_{8} \mathrm{O}_{2}$ & 2.0 & 3.8 & 2.4 & 0.9 \\
\hline 15 & 5-Methyl-2(5H)-furanone & 98 & $\mathrm{C}_{5} \mathrm{H}_{8} \mathrm{O}_{2}$ & 0.9 & 1.1 & & \\
\hline 16 & 3-Methyl-2(5H)-furanone & 98 & $\mathrm{C}_{5} \mathrm{H}_{6} \mathrm{O}_{2}$ & 0.7 & 0.9 & & \\
\hline 17 & 3-Hydroxybenzaldehyde & 122 & $\mathrm{C}_{7} \mathrm{H}_{8} \mathrm{O}_{2}$ & & & 0.1 & \\
\hline 18 & Cyclopentanone & 84 & $\mathrm{C}_{5} \mathrm{H}_{8} \mathrm{O}$ & 2.5 & 2.8 & 0.5 & \\
\hline 19 & 2-Pyrone & 96 & $\mathrm{C}_{5} \mathrm{H}_{4} \mathrm{O}_{2}$ & & & 0.6 & \\
\hline 20 & 1,3-Cyclopentanedione & 98 & $\mathrm{C}_{5} \mathrm{H}_{6} \mathrm{O}_{2}$ & 3.6 & 6.2 & 1.6 & \\
\hline 21 & 4H-Pyran-4-one & 96 & $\mathrm{C}_{5} \mathrm{H}_{4} \mathrm{O}_{2}$ & & 1.5 & & \\
\hline 22 & 2-Hydroxy-3-methyl-2-cyclopenten-1-one & 112 & $\mathrm{C}_{6} \mathrm{H}_{8} \mathrm{O}_{2}$ & 2.3 & 2.1 & 0.5 & 1.8 \\
\hline 23 & 3-Methyl-2,4(3H,5H)-furandione & 114 & $\mathrm{C}_{5} \mathrm{H}_{8} \mathrm{O}_{3}$ & 5.1 & & & \\
\hline 24 & 3-Hydroxy-2-methylpyran-4-one & 126 & $\mathrm{C}_{8} \mathrm{H}_{8} \mathrm{O}_{3}$ & 10.0 & 1.1 & & \\
\hline 25 & 1,4-Dimethoxybenzene & 138 & $\mathrm{C}_{8} \mathrm{H}_{10} \mathrm{O}_{2}$ & & & & 1.3 \\
\hline 26 & a Furancarboxylic acid methyl ester & 126 & $\mathrm{C}_{6} \mathrm{H}_{6} \mathrm{O}_{3}$ & 6.9 & 1.4 & 2.0 & \\
\hline 27 & Phenol + o-cresol & $94+108$ & $\mathrm{C}_{6} \mathrm{H}_{6} \mathrm{O}+\mathrm{C}_{7} \mathrm{H}_{8} \mathrm{O}$ & 0.9 & 1.3 & 0.7 & 12.3 \\
\hline 28 & $m$-Cresol + p-cresol & 108 & $\mathrm{C}_{7} \mathrm{H}_{8} \mathrm{O}$ & 0.7 & 0.5 & 0.5 & 16.6 \\
\hline 29 & 4-Ethyiphenol & 122 & $\mathrm{C}_{8} \mathrm{H}_{10} \mathrm{O}$ & & & & 2.6 \\
\hline 30 & 2-Ethyl-5-methylphenol & 136 & $\mathrm{C}_{9} \mathrm{H}_{12} \mathrm{O}$ & & & & 1.3 \\
\hline 31 & an Ethyl dimethyl phenol & 150 & $\mathrm{C}_{10} \mathrm{H}_{14} \mathrm{O}$ & & & & 0.6 \\
\hline 32 & 3,4-Dimethoxyphenol & 154 & $\mathrm{C}_{8} \mathrm{H}_{10} \mathrm{O}$ & & & & 0.7 \\
\hline
\end{tabular}


Flgure 1.

Glass capillary gas chromatography (GC-2) separation of the pyrolysis products of cellulose on an SP-1000 column (peak identifications in Table 1).

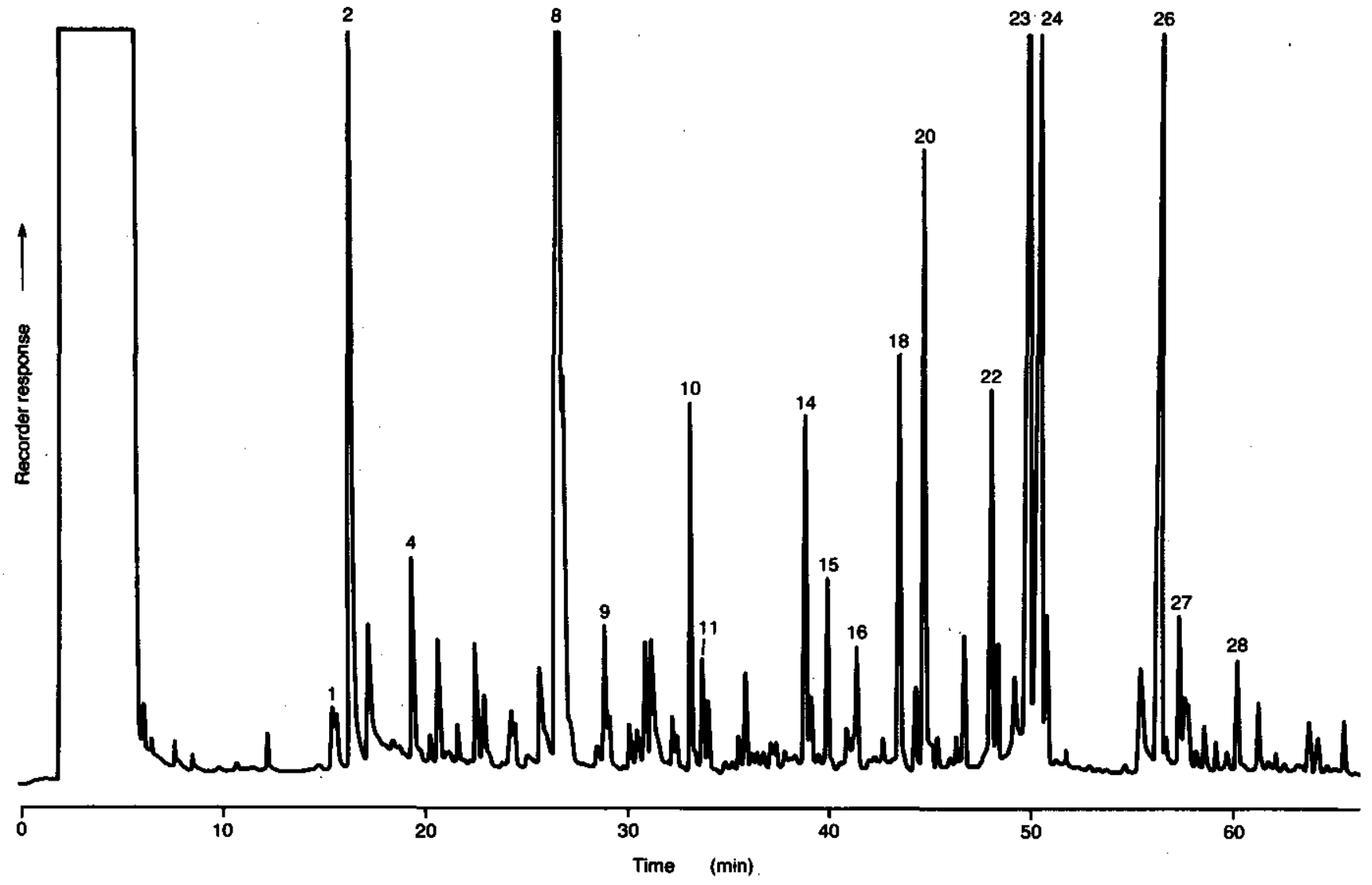

Figure 2.

GC-2 chromatogram of dextrln pyrolysis products (peak identifications in Table 1).

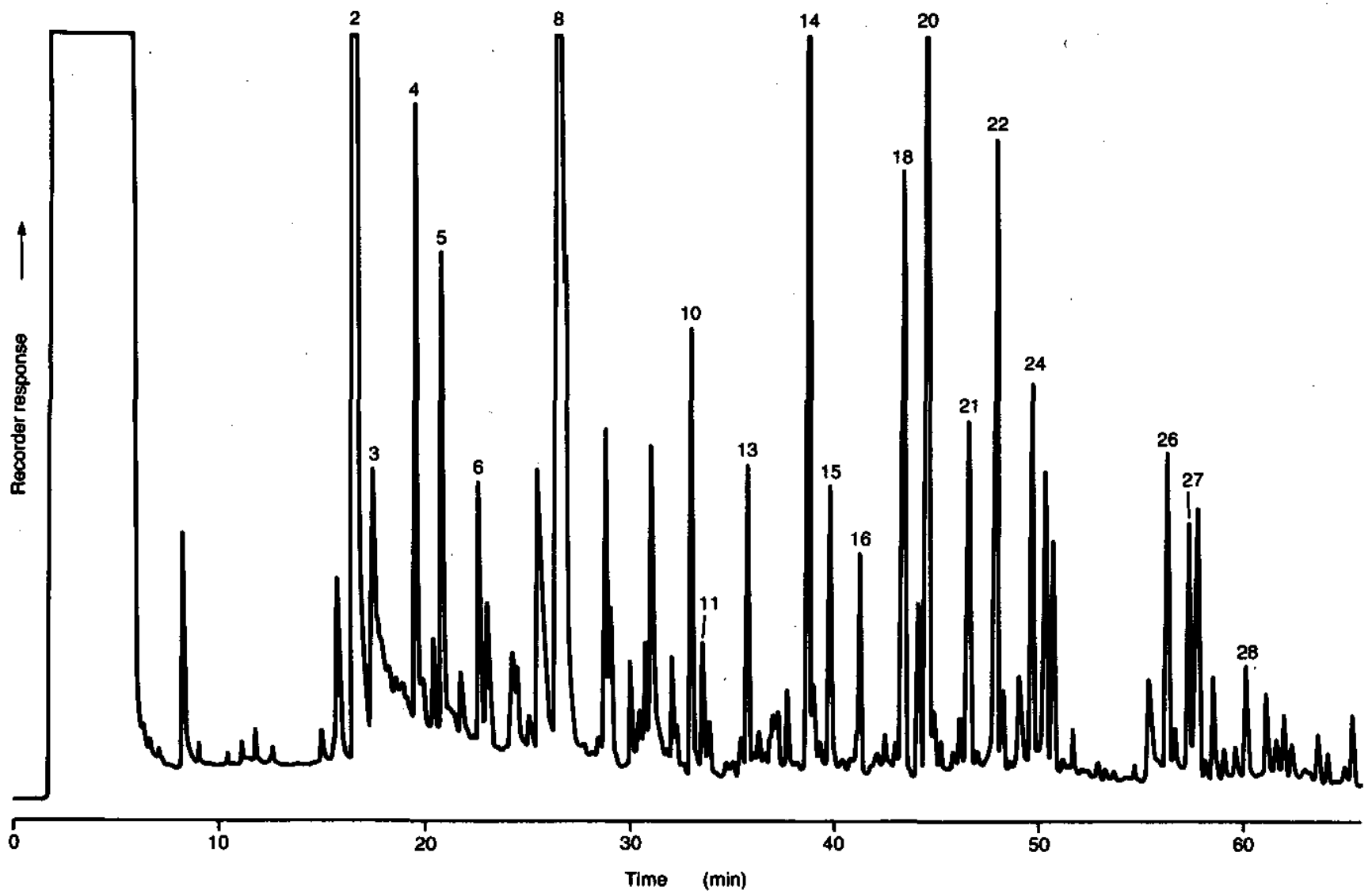


Figure 3.

GC-2 chromatogram of sucrose pyrolysis products (peak identifications in Table 1).

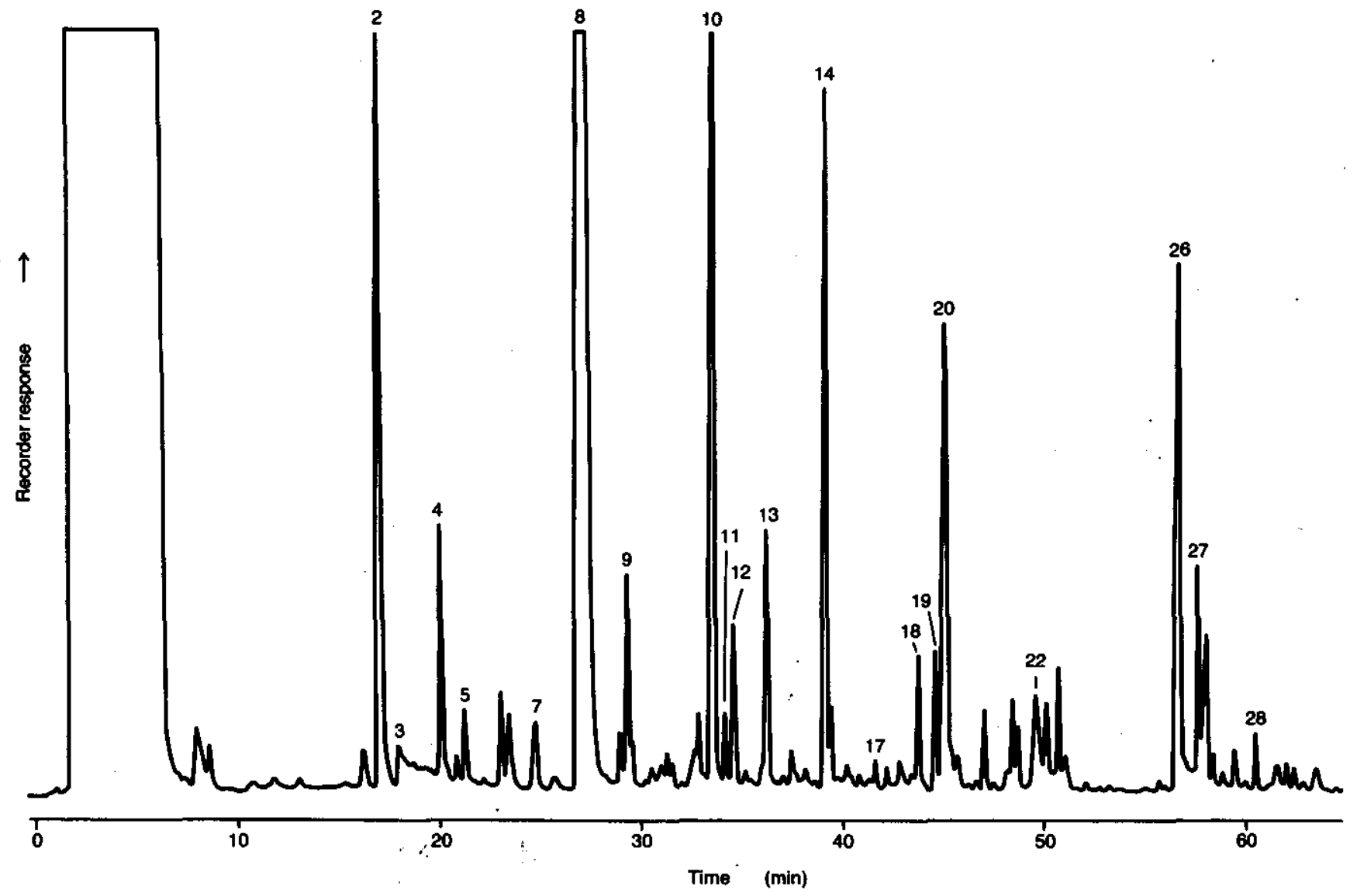

Figure 4.

GC-2 chromatogram of lignin pyrolysis products (peak identifications in Table 1).

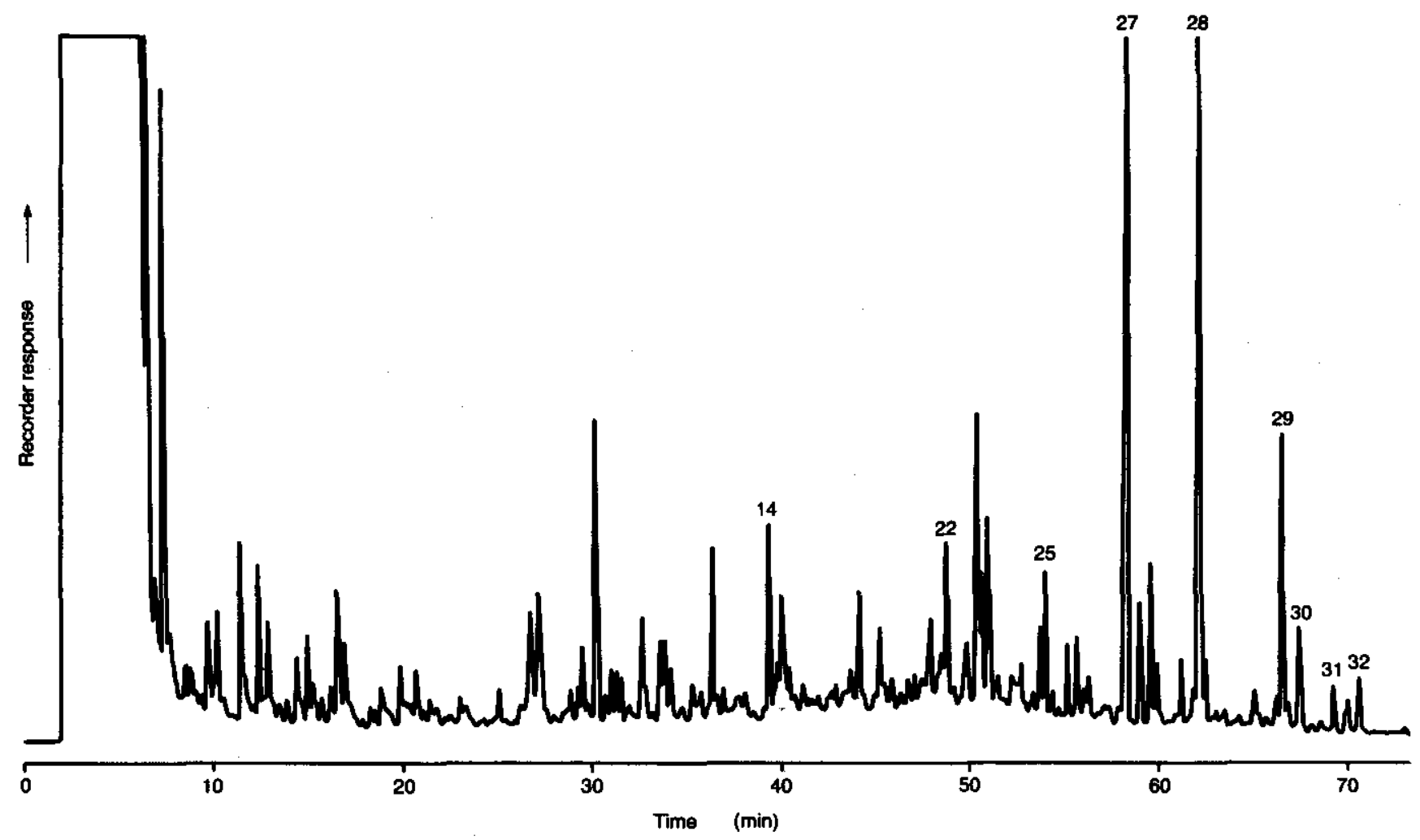


bacco flavor and aroma, we collected and analyzed the pyrolyzates without derivatization or other chemical alterations which proscribe accurate flavor evaluations and may lead to artifact formation. The volatile pyrolysis products identified from our chromatogram (Fig. 1) are similar to those reported by Sakuma (18). The presence of 3-hydroxy-2-methylpyran-4-one (peak 24 in Fig. 1) in significant amounts is of particular interest from a flavor aspect, as the pyran-4-ones are important Maillard-Browning reaction intermediates in the formation of substituted furanones, found in cooked and dehydrated foods (19). Both pyran-4-ones and furanones have also been identified in the total particulate matter of cigarette smoke (16).

Although starch is an important constituent of Bright tobaccos, ranging from an average of $15 \%$ dry weight of fresh green leaf to $3 \%$ of cured leaf (20), few studies have been published concerning the fate of tobacco starch in the burning cigarette. Newell (21), in a study with ${ }^{14} \mathrm{C}$-labeled carbohydrates, reported that tobacco starch contributes a higher percentage of thermal decomposition products to mainstream smoke than other cell-wall components. In our study, pyrolysis of dextrin, as a representative plant starch, yielded a chromatographic profile (Fig. 2) qualitatively similar to cellulose. However, 3-methylfuran was present in greater amounts in dextrin vs. cellulose pyrolyzate, whereas 3-hydroxy-2-methylpyran-4-one was greatly reduced. The parent compound, 4H-pyran-4-one (peak 21 in Fig. 2), was a significant product of dextrin pyrolysis, but was not positively identified in the cellulose pyrolyzate. The data suggest that cellulose and starch undergo parallel thermal decomposition mechanisms; thus, the combined amounts of these components in cigarette blends should significantly affect the levels of furans and cyclic ketones in smoke and smoke flavor in general.

In contrast to the polymeric carbohydrates, the pyrolysis profile of sucrose (Fig. 3) suggested a thermal decomposition pathway of less complexity. 2-Furaldehyde (peak 8) was 67\% of the total GC-2 volatile sucrose pyrolyzate (compared to $21 \%$ and $17 \%$ for cellulose and dextrin pyrolysis, respectively). Identification of silylated derivatives of pyrolyzate products of glucose, fructose and sucrose (13) indicated 5-hydroxymethyl furfural to be the major component. Recent studies (22) indicate that the optimum temperature for pyrogenesis of this compound from sucrose, under nitrogen, is approximately $450^{\circ} \mathrm{C}$. Yields of 2-furaldehyde, however, were greatest at $650^{\circ} \mathrm{C}$. Johnson (23) identified furans and cyclic ketones, after heating sucrose with a gas burner. However, confirmation that 2-furaldehyde is the most significant smoke product of the sugar in the cigarette can be found in the data of Thomton (5) addition of sugars to cigarettes resulted in no significant change in total aldehyde and ketone delivery in smoke, but gave an observable increase in 2-furaldehyde levels.

Lignin was included in this study, since it is closely associated with the cell-wall polysaccharides in tobacco leaf. The chromatographic profile of lignin pyrolyzate (Fig. 4) consisted essentially of phenol, cresols and other substituted monophenols, as expected from previous studies $(14,24)$. The presence of 2 -furanmethanol and 2-hydroxy-3-methyl-2-cyclopenten-1-one in lignin pyrolyzate, compounds common to the three carbohydrate pyrolyzates, is most likely the result of incomplete separation of cellulose from lignin during our extraction procedure. It is safe to conclude that lignin makes a minor contribution, if any, to the flavor significant compounds produced by thermal decomposition of carbohydrates.

\section{REFERENCES}

1. Schlotzhauer, W. S., O. T. Chortyk and R. F. Severson: Rapid pyrolytic method for evaluating effect of tobacco variety, growing, harvesting, and post-harvest treatment on smoke composition; Tob. Sci. 23 (1979) 103-106.

2. Stedman, R. L.: The chemical composition of tobacco and tobacco smoke; Chem. Rev. 68 (1968) $153-207$.

3. Chortyk, O. T., and W. S. Schlotzhauer: Studies on the pyrogenesis of tobacco smoke constituents A review; Beitr. Tabakforsch. 7 (1973) 165-178.

4. Gager, F. L., Jr., J. W. Nedlock and W. J. Martin: Tobacco additives and cigarette smoke, II. Organic gas-phase products from D-glucose and sucrose; Carbohydr. Res. 7 (1971) 327-330.

5. Thornton, R. E., and S. R. Massey: Some effects of adding sugar to tobacco; Beitr. Tabakforsch. 8 (1975) 11-15.

6. Ohnishi, A., and $\mathrm{K}$. Kato: Thermal decomposition of tobacco cell-wall polysaccharides; ibid. 9 (1977) 147-152.

7. Braven, J., G. J. Bonker, M. L. Fenner and B. L. Tonge: Mechanism of carcinogenesis by tobacco smoke - Observations and a hypothesis; Br. J. Cancer 21 (1967) 623-633.

8. Elson, L. A, and T. C. Betts: Sugar content of tobacco and $\mathrm{pH}$ of the smoke in relation to lung cancer risks of cigarette smoke; J. Natl. Cancer Inst. 48 (1972) 1885-1890.

9. Pepper, J. M., and P. D. S. Wood: Isolation of a representative lignin fraction from wood and straw meals; Can. J. Chem. 40 (1962) 1026-1028.

10. Thome, F. A., G. W. Young and W. C. Hamlin, Jr.: Applications of pyrolysis-gas chromatographymass spectrometry to tobacco chemistry (1982 Coresta Symposium, Winston-Salem, N.C.); coresta Information Bulletin - Special Issue 1982, No. S12, p. 22.

11. Arrendale, R. F., R. F. Severson and O. T. Chortyk: Preparation of wall-coated open tubular glass (Pyrex) capillary columns with polar stationary phases, using Superox ${ }^{\mathrm{TM}}-4$ as a surface pretreating and deactivating agent; J. Chromatogr. 208 (1981) 209-216. 
12. Stenhagen, E., S. Abrahamsson and F. W. McLafferty (eds.): Registry of mass spectral data; John Wiley and Sons, Inc., New York, N.Y., U.S.A., 1974.

13. Saint-Jalm, Y.: Qualitative analysis of the hydroxyl fraction of cigarette smoke; Ann. Tab. 18 (1981) $41-48$.

14. Schlotzhauer, W. S., R. M. Martin, M. E. Snook and R. E. Williamson: Pyrolytic studies on the contribution of tobacco leaf constituents to the formation of smoke catechols; J. Agric. Food Chem. 30 (1982) 372-374.

15. Guerin, M. R., G. Olerich and A. D. Horton: Routine gas chromatographic component profiling of cigarette smoke for the identification of biologically significant compounds; J. Chromatogr. Sci. 12 (1974) 385-391.

16. Ishiguro, S., and S. Sugawara: Gas chromatographic analysis of cigarette smoke by trimethylsilylation method; Beitr. Tabakforsch. Int. 9 (1978) 218-221.

17. Gardiner, D.: The pyrolysis of some hexoses and derived di-, tri- and poly-saccharides; J. Chem. Soc. (London) Section C 1966, 1473-1476.

18. Sakuma, H., S. Munakata and S. Sugawara: Volatile products of cellulose pyrolysis; Agric. Biol. Chem. 45 (1981) 443-451.

19. Mills, F. D.: Ring contraction products from 2,3-dihydro-3,5-dihydroxy-6-methyl-4(H)-pyran-4one: 4-hydroxy-5-hydroxymethyl-2-methyl-3(2H)furanone and 2,5-dimethyl-4-hydroxy-3(2H)-furanone; J. Agric. Food Chem. 26 (1978) 894-898.

20. Oakley, E. T.: Enzymatic determination of starch in fresh green, lyophilized green, and cured tobacco; ibid. 31 (1983) 902-905.
21. Newell, M. P., and F. W. Best: Fate of compounds in the burning cigarette / Polymeric carbohydrates: pectins, starch, cellulose; 25th Tobacco Chemists' Research Conference, 1971, Lexington, Kentucky, U.S.A., abstract No. 11.

22. Schlotzhauer, W. S., R. F. Severson, R. M. Martin and $\mathrm{K} . \mathrm{L}$. McDuffie: The contribution of sucrose esters to tobacco smoke composition; 38th Tobacco Chemists' Research Conference, 1984, Atlanta, Ga., U.S.A., abstract No. 31.

23. Johnson, R. R., E. D. Alford and G. W. Kinzer: Formation of sucrose pyrolysis products; J. Agric. Food Chem. 17 (1969) 22-24.

24. Kato, K. F., F. Sakai and T. Nakahata: Thermal decomposition of tobacco lignin; Jpn. Monop. Corp. Cent. Res. Inst. Sci. Pap. 107 (1965) 171-175.

\section{Acknowledgements}

The autbors thank Mr. Robert M. Martin for bis assistance in preparing glass capillary columns used in this study and for assistance with the analytical data.

\author{
Authors'address: \\ Tobacco Safety Research Unit, \\ Agricultural Research Service, \\ U.S. Department of Agriculture, \\ P.O. Box 5677 , \\ Atbens, Georgia, 30613, U.S.A.
}

